\title{
Clinical and laboratory aspects of raised virus antibody titres in systemic lupus erythematosus
}

\author{
N. F. ROTHFiELD, A. S. EVANS, AND J. C. NIEDERMAN \\ From the Department of Medicine, University of Connecticut School of Medicine, and the W.H.O. Serum \\ Reference Bank, Department of Epidemiology and Public Health, Yale University School of Medicine, U.S.A.
}

A possible role of virus infection in the pathogenesis of systemic lupus erythematosus (SLE) has been postulated. This concept has been supported by the demonstration by Mellors, Shirai, Aoki, Huebner, and Krawczynski (1971) and Levy and Pincus (1970) of a role of virus infection in the disease of New Zealand mice (NZB) which is a model of SLE (Howie and Helyer, 1968); by reports of microtubular structures in glomerular endothelium from SLE patients (Fresco, 1968; Grausz, Earley, Stephens, Lee, and Hopper, 1970; and Norton, 1969) and by the occurrence of high antibody titres to measles, rubella, and parainfluenza 1 viruses (Phillips and Christian, 1970; Hurd, Dowdle, Casey, and Ziff, 1972; Hollinger, Sharp, Lidsky, and Rawls, 1971; Feltkamp, van Loghem, Lucas, van der Noordaa, de Rooy, and ten Veen, 1971) in SLE patients as compared to controls.

High antibody titres to the Epstein-Barr (EB) virus have also been reported by Dalldorf, Carvalho, Jamra, Frost, Erlich, and Marigo (1969), and in a larger survey of our own (Evans, Rothfield, and Niederman, 1971), to be present in SLE patients as compared to controls.

The present study expands our previous preliminary communication on the increase of the four virus antibodies in SLE as compared to control subjects and in contrast to normal or decreased antibody levels for seven other viruses. We here present the relation of the raised antibody titres of the four viruses to epidemiological, clinical, and laboratory features of SLE. The data here presented also include serial observations over prolonged periods on several patients. On the basis of the evidence found, the EB virus may be a likely candidate for participation in the aetiology and pathogenesis of SLE in some patients.

\section{Material and methods}

Single serum samples from 100 patients with SLE were tested against EB virus and about thirty of these to ten other viruses. All patients had multiple system disease typical of SLE (Rothfield, Phythyon, McEwen, and Miescher, 1961) and met the criteria for the diagnosis of SLE(Cohen, Reynolds, Franklin, Kulka, Ropes, Shulman, and Wallace, 1971). Antinuclear antibodies (ANA) and positive LE cell preparations were present in all patients at some time during the course of their disease but not necessarily when the serum sample was obtained. Their ages ranged from 4 to 78 years, thirteen being under the age of 20 years. Clinical status and the therapy used in each subject were evaluated when the serum was obtained and all laboratory tests were performed on the single sample from each patient.

Disease activity was graded from 0 to 3 , using the following criteria:

Grade 0, remission: considered to be present when the patient was asymptomatic and when fever or acute physical abnormalities were absent regardless of whether or not the patient was receiving corticosteroid or other therapy (chronic abnormalities, such as atrophic skin lesions, pigmentation, and chronic proteinuria were regarded as compatible with remission);

Grade 1: involvement of one system without fever-that is, arthralgia, or arthritis, rash, or mucosal ulcer;

Grade 2: low grade fever and involvement of at least two systems, or involvement of at least two systems without fever;

Grade 3: temperature higher than $102^{\circ} \mathrm{F}$. and involvement of at least two systems.

For comparison, sera were also tested from 34 patients with tuberculosis from the same hospital population who could be matched with respect to age within 4 years, sex, and race with 34 of the 100 SLE patients. Eight of the tuberculosis patients had received anti-tuberculosis therapy (isoniazid) at the time serum was obtained; 26 
were studied before the institution of such therapy. None of the tuberculosis patients had clinical or serological evidence of a drug-induced lupus syndrome. Sera from 255 healthy controls tested for the presence of EB virus antibody were obtained from adults in blood banks, maternity clinics, and military services. Forty of these control sera were matched for age within 5 years, sex, and race to forty of the SLE patients.

Antibody to EB virus was determined in the WHO Serum Reference Laboratory at Yale University by an indirect immunofluorescence technique utilizing the EB3-cell line and a single lot of fluorescein-isothiocyanate conjugated anti-IgG prepared in goats (Hyland Laboratory) by the method of Henle and Henle (1966). A Leitz microscope with Osram 200 bulb, OG1, and BG 12 exciter filters, and $\mathrm{K} 420$ ocular filter was used.

In the EB3 system about 2 to 5 per cent. of cells show fluorescence with EB virus immune serum; the fluorescence is intracellular and quite characteristic. The highest serum dilution with a few definitely positive cells at $400 \times$ magnification was taken as the end-point. In addition to this fluorescence, many SLE sera showed antinuclear and anticytoplasmic fluorescence with EB3 cells. This was diffuse, involved over half the cells, and consisted of peripheral, reticular, and spotty fluorescence. However, at dilutions of approximately $1: 40$, the antinuclear effect was usually no longer present permitting ready identification of EB virus infected cells. At dilutions considered elevated for EB virus antibody, namely 1:320 or higher, no confusion with the antinuclear antibody (ANA) was seen although a faint reticular fluorescence was occasionally observed in many cells.

Results were read independently by two of us and positive and negative controls were included in each individual titration. Agreement in anti-EB virus level between readers was over 95 per cent.

ANA were measured in the University of Connecticut Laboratory by an indirect immunofluorescence test (Rothfield and Stollar, 1967), using cryostat-cut sections of mouse liver as a score of nuclei and a single lot of fluorescein isothiocyanate conjugated anti-human $\mathrm{IgG},{ }^{*}$ which was cleaned by passing through a DEAE column and gave a single line on immunoelectrophoresis against normal human serum. DNA-binding using tritiated thymidine DNA from E. coli (Luciano and Rothfield, 1972) was determined by the technique of Wold, Young, Tan and Farr (1968).

Heterophil antibody titres were determined with sheep red cells by a microtitre method before and after absorption of serum with guinea-pig kidney. Other virus antibodies were determined on microtitre plates with conventional techniques. These included haemagglutination inhibition (HI) tests for influenza, parainfluenza 1, 2, 3 viruses, and measles virus. For influenza, sera were pretreated with receptor destroying enzyme (RDE), for parainfluenza, these were absorbed with guinea-pig cells, and for measles were pre-treated with kaolin. Complementfixation (CF) titres, determined by the 50 per cent. endpoint on microtitre plates, were performed for herpes simplex virus, adenovirus, and cytomegalovirus by the method of the Center for Disease Control, Atlanta, Georgia (CDC). Pre-treatment of sera with Dextran and the method of titration for rubella $\mathrm{HI}$ test followed that of

\footnotetext{
* From Antibodies Incorporated, Davis, California.
}

Liebhaber (1970). Positive and negative serum controls and antigen controls were included in each run. Anticomplementary sera were treated with complement at $4^{\circ} \mathrm{C}$. overnight then re-activated. The results in sera from SLE patients were compared for many of the antibodies with titres from healthy controls whose sera had been tested by the same technicians and by the same methods. They were also compared with matched patients with tuberculosis mentioned above.

C3 was determined using radial immunodiffusion. * Each serum was tested in duplicate. IgG was measured in duplicate using radial immunodiffusion. $\dagger$

Absorption of ANA was carried out using purified calf thymus nucleoprotein (DNA content $1,500 \mu \mathrm{g} . / \mathrm{ml}$.) obtained from Dr. David S. Stollar. Absorbed and unabsorbed sera were coded and read as unknowns in the test for EB virus antibody. Rheumatoid factor was determined by the latex-fixation technique of Singer and Plotz (1956).

Student's ' $t$ ' test was employed in comparing matched and unmatched results between SLE and control sera. The geometric mean antibody titre was calculated by converting all positive titres to $\log 2$ base, averaging, and reconverting to the titre. For purposes of comparison in the matched ' $t$ ' test with SLE and Tb sera, it was assumed that sera negative at the lowest dilution tested (usually $1: 10)$ were positive at the next lower dilution. For all other comparisons, only sera with demonstrable antibody were included in calculating the geometric mean titre or the frequency of elevated titres. The mean antibody score or titre was also calculated for groups of viruses; comparisons were made by Student's ' $t$ ' test adding the $\log 2$ titres for the titres found in each SLE serum and comparing this with the results for the same tests in the serum from the matched control. All eleven antibody tests were carried out on each of the 25 matched pairs compared by this technique.

\section{Results}

\section{EB VIRUS ANTIBODY}

92 sera from 100 cases of systemic lupus erythematosus had EB virus antibody present as compared with $87 \cdot 1$ per cent in sera from 255 healthy controls. Among those with antibody, 45.7 per cent. of the SLE sera and 8.1 per cent. of the control sera had raised titres at levels of $1: 320$ or higher. The geometric mean titres (GMT) were $1: 196.7$ and $1: 61.9$ respectively. The distribution of these titres is shown in Fig. 1 (overleaf).

A comparison of EB virus antibody titres was also made on a subsample of 34 SLE patients with 34 patients with tuberculosis matched by age, sex, race, and hospital. The geometric mean titres were $1: 216 \cdot 8$ in the SLE sera and 1:35.3 in the Tb sera $(\mathrm{P}<0.001$ by the matched ' $t$ ' test). In SLE sera 52.9 per cent. had titres $1: 320$ as compared to 2.9 per cent. in the matched $\mathrm{Tb}$ patients $(\mathrm{P}<0.001)$.

\footnotetext{
* (Immuno-plate Human Complement C3 test, Hyland Division, Travenol Laboratories, Inc., Costa Mesa, California).

† (Immuno-plate Human IgG test, Hyland Division, Traveno Laboratories, Costa Mesa, California).
} 


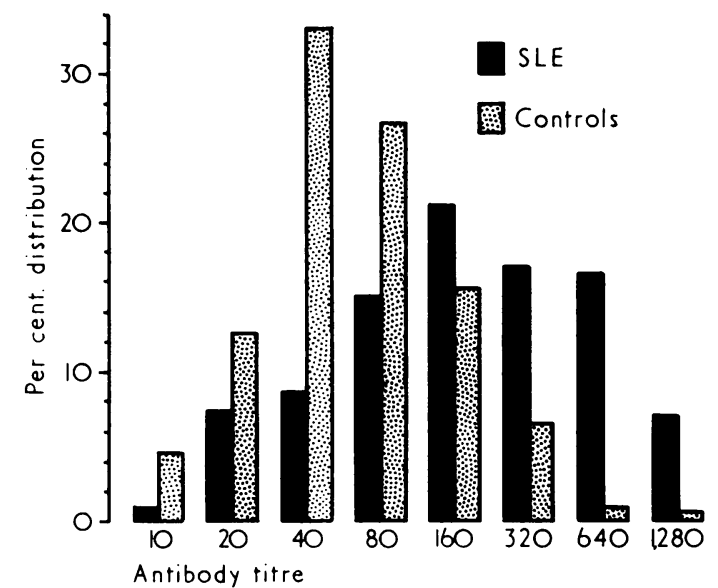

FIG. 1 Percentage distribution of EB virus antibody titre in sera with antibody from 92 SLE patients and 222 normal individuals

Because fluorescence to both ANA and to EB virus antibody was seen with EB3 cells, examination of a possible correlation was of the highest importance to determine whether we might be reading the same antibody. As indicated in Fig. 2, no such correlation existed. Indeed, seven patients had no demonstable ANA, even in undiluted serum, yet three of these had EB virus titres of $1: 160$ or higher. Similarly among the eight sera lacking EB virus antibody in the lowest dilution tested, all eight had ANA antibody with titres ranging from $1: 32$ to $1: 1024$. Further differentiation was shown by absorption of ANA with calf thymus nucleoprotein. In six SLE sera containing both antibodies, nucleoprotein absorption markedly reduced antinuclear antibody titre but failed to affect the level of anti-EB virus antibody (Table I).

Table I Effect of absorption of serum with nucleoprotein on titre of $A N A$ and $E B$ virus antibody $(E B V A)$

\begin{tabular}{|c|c|c|c|c|}
\hline \multirow[t]{2}{*}{ Serum } & \multicolumn{2}{|c|}{ ANA 1/titre } & \multicolumn{2}{|c|}{ EBVA 1/titre } \\
\hline & Control & Absorbed & Control & Absorbed \\
\hline $\begin{array}{l}\text { D.T. } \\
\text { R.K. } \\
\text { G.D.M. } \\
\text { C.F. } \\
\text { A.T. } \\
\text { M.O. }\end{array}$ & $\begin{array}{r}320 \\
160 \\
40 \\
80 \\
220 \\
160\end{array}$ & $\begin{array}{l}40 \\
20 \\
\text { Neg. } \\
20 \\
10 \\
\text { Neg. }\end{array}$ & $\begin{array}{l}800 \\
800 \\
200 \\
400 \\
100 \\
160\end{array}$ & $\begin{array}{l}800 \\
400 \\
100 \\
800 \\
100 \\
160\end{array}$ \\
\hline
\end{tabular}

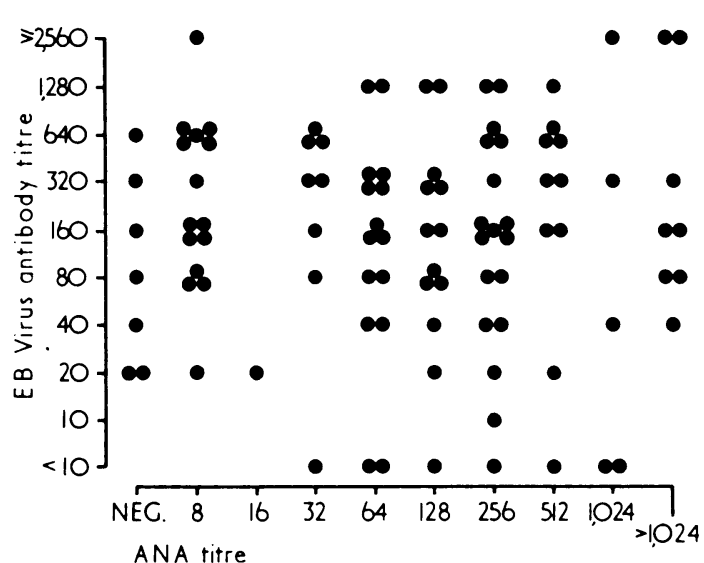

FIG. 2 Relation between EB virus and antinuclear antibody titres in 92 patients with SLE

\section{OTHER VIRUS ANTIBODIES}

The geometric mean antibody titres (GMT) for ten other virus antigens in sera from patients with SLE $\overrightarrow{0}$ were compared with sera from healthy controls as $\omega$ well as with sera from patients with tuberculosis matched for age, sex, and race. Only three antibodies (rubella, measles, and parainfluenza 1) were significantly raised in SLE as compared to the controls and tuberculosis patients. These results are shown in Table II. The geometric mean titre in 68 SLE sera possessing rubella antibody was $1: 51 \cdot 7$ as compared to $1: 39.3$ in sera from 192 healthy controls $(\mathrm{P}<0.05)$. In SLE sera matched with sera from tuberculosis patients, the rubella titres were $1: 70$ and $1: 27 \cdot 8$ respectively $(P<0.01)$. Measles antibody titres were $1: 46.2$ in 58 SLE sera. In the matched pairs the titres were $1: 34 \cdot 8$ for SLE and $1: 14 \cdot 1$ for tuberculosis sera $(\mathrm{P}<0.025)$. The geometric mean titre was $1: 24$ for parainfluenza 1 in SLE sera as compared with $1: 17 \cdot 6$ in healthy controls $(P<0.025)$ and $1: 10$ in tuberculosis control sera $(\mathrm{P}<0.005)$. No significant difference in antibody titre to rubella or to parainfluenza 1 was found between healthy controls and tuberculosis patients. No correlation between the titre of ANA and the titre of any of these three antibodies was found.

As shown in Table III (opposite), the geometric mean titres of influenza $A 2$, influenza $B$, parainfluenza 2 , and parainfluenza 3 tested by the haemagglutination-inhibition test in SLE sera were equal to or less

Table II Antibody titres for rubella, measles, and parainfluenza 1 antibodies in SLE and control sera

\begin{tabular}{|c|c|c|c|c|c|c|c|c|c|c|}
\hline \multirow[t]{2}{*}{ Antibody } & \multirow[t]{2}{*}{ Test } & \multicolumn{2}{|c|}{$S L E$} & \multicolumn{3}{|c|}{ Healthy controls } & \multicolumn{4}{|c|}{ Matched Tb controls GMT* } \\
\hline & & No. & $G M T^{*}$ & No. & $G M T^{*}$ & $\mathbf{P}$ & No. & $S L E$ & $T b$ & $\mathbf{P}$ \\
\hline $\begin{array}{l}\text { Rubella } \\
\text { Measles } \\
\text { Para } 1\end{array}$ & $\begin{array}{l}\text { HI } \\
\text { HI } \\
\text { HI }\end{array}$ & $\begin{array}{l}68 \\
58 \\
26\end{array}$ & $\begin{array}{l}51 \cdot 7 \\
46 \cdot 2 \\
24 \cdot 1\end{array}$ & $\begin{array}{l}\overline{192} \\
\text { Non } \\
1572\end{array}$ & $\begin{array}{l}39 \cdot 3 \\
\text { sted } \\
17 \cdot 6\end{array}$ & $\begin{array}{l}<0.05 \\
<0.025\end{array}$ & $\begin{array}{l}30 \\
30 \\
28\end{array}$ & $\begin{array}{l}70 \cdot 0 \\
34 \cdot 8 \\
20 \cdot 0\end{array}$ & $\begin{array}{l}27 \cdot 8 \\
14 \cdot 1 \\
10 \cdot 3\end{array}$ & $\begin{array}{l}<0.01 \\
<0.025 \\
<0.005\end{array}$ \\
\hline
\end{tabular}


Table III Antibody titres for influenza, parainfluenza 2 and 3, herpes simplex, cytomegalovirus, and adenovirus in SLE and control sera

\begin{tabular}{|c|c|c|c|c|c|c|c|}
\hline \multirow[t]{3}{*}{$\overline{T e s t}$} & \multirow[t]{3}{*}{ Virus antigen } & \multicolumn{2}{|l|}{$S L E$} & \multicolumn{4}{|c|}{ Controls } \\
\hline & & \multirow[t]{2}{*}{ No. } & \multirow[t]{2}{*}{$G M T^{*}$} & \multicolumn{2}{|c|}{ Healthy } & \multirow{2}{*}{$\begin{array}{l}\text { Matched } \\
\text { No. }\end{array}$} & \multirow{2}{*}{$\frac{T b}{G M T^{*}}$} \\
\hline & & & & No. & $G M T^{*}$ & & \\
\hline HI & $\begin{array}{c}\text { Influenza }{ }_{B}^{A 2} / T \\
\text { Parainfluenza } 2 \\
2\end{array}$ & $\begin{array}{l}20 \\
19 \\
24 \\
25\end{array}$ & $\begin{array}{l}31 \cdot 4 \\
32 \cdot 1 \\
17 \cdot 8 \\
32 \cdot 9\end{array}$ & $\begin{array}{r}912 \\
1,774 \\
1,563 \\
2,039\end{array}$ & $\begin{array}{l}33 \cdot 1 \\
28 \cdot 8 \\
20 \cdot 0 \\
42 \cdot 1\end{array}$ & $\begin{array}{l}28 \\
22 \\
27 \\
28\end{array}$ & $\begin{array}{l}49 \cdot 9 \\
25 \cdot 7 \\
19 \cdot 0 \\
44 \cdot 0\end{array}$ \\
\hline$\overline{\mathrm{CF}}$ & $\begin{array}{l}\text { Herpes simplex } \\
\text { Cytomegalovirus } \\
\text { Adenovirus }\end{array}$ & $\begin{array}{l}24 \\
23 \\
17\end{array}$ & $\begin{array}{r}10 \cdot 0 \\
11 \cdot 3 \\
6 \cdot 6\end{array}$ & $\begin{array}{l}67 \\
36 \\
45\end{array}$ & $\begin{array}{l}27 \cdot 6 \\
20 \cdot 4 \\
14 \cdot 5\end{array}$ & $\begin{array}{l}26 \\
26 \\
20\end{array}$ & $\begin{array}{l}23 \cdot 5 \\
14 \cdot 9 \\
12 \cdot 3\end{array}$ \\
\hline
\end{tabular}

* GMT based on persons with antibody only. $\mathrm{HI}=$ hemagglutination-inhibition; $\mathrm{CF}=$ complement fixation.

than those in a large group of healthy controls or to age and sex matched patients with tuberculosis. Titres of complement fixing antibodies to herpes simplex virus, adenovirus, and cytomegalovirus were somewhat lower in sera of SLE patients than in sera from healthy controls or patients with tuberculosis.

\section{MATCHED SUBSAMPLE}

To avoid bias, a subsample of forty patients with SLE was matched by age (within 5 years), sex, and race with 40 healthy adults. The geometric mean titres for eleven antibodies were compared using Student's matched and paired t tests; the per cent. with raised antibody titres was calculated and compared by the $\chi^{2}$ test. By these rigorous criteria, statistically significant differences by all three tests were found only for EB virus and rubella antibodies between SLE and control groups. The pertinent data is given in Table IV.

\section{RELATION OF RAISED ANTIBODY TITRES TO} AGE AND SEX

The geometric mean titres of EB virus, rubella, measles, and parainfluenza 1 viruses and of ANA were analysed in relation to a number of epidemiological and clinical variables. The geometric mean titres calculated in this comparison were based on the titres in sera showing demonstrable antibody because we wished to determine if these variables were associated with increased antibody levels.

Fig. 3 (overleaf) shows the relationships between these four antibody levels and the age of the SLE patients. ANA decreased with age. This probably reflects less active disease in older patients at the time of study. EB virus and rubella titres were higher in the first 30 years, dropped off, then rose again after $\mathbf{5 0}$ years. No age correlation was seen for measles or parainfluenza antibodies but the numbers were small.

Table V (overleaf) shows that ANA and EB virus antibody titres were somewhat higher in females than in males, while the reverse was true for other antibodies. No impressive racial differences in any of the four antibody titres were seen.

\section{CLINICAL ACTIVITY}

As shown in Fig. 4 (overleaf), ANA levels increased with increasing clinical activity. EB virus antibody titres showed exactly the opposite trend; i.e. the highest mean EB virus antibody titres occurred when clinical activity was absent and declined as signs and symptoms of severity increased. 49 per cent. of all patients had EB virus antibody titres greater than $1: 160$, whereas only 26.7 per cent. of these with severe disease at the time of study had levels in this range. No

Table IV Comparison of EB virus and rubella antibody titres in forty SLE patients matched by age, sex, and race with forty controls

\begin{tabular}{|c|c|c|c|c|c|c|c|}
\hline \multirow[t]{2}{*}{ Antibody } & \multirow[t]{2}{*}{ Group } & \multirow{2}{*}{$\begin{array}{l}\text { No. with } \\
\text { antibody }\end{array}$} & \multicolumn{3}{|c|}{ Per cent. above level shown* } & \multicolumn{2}{|c|}{ Geometric mean titre* } \\
\hline & & & Level & Per cent. & $\begin{array}{l}\text { P value } \\
\text { by } \chi^{2}\end{array}$ & Titre & $\begin{array}{l}\text { P value } \\
\text { by paired } \\
\text { t test }\end{array}$ \\
\hline$\overline{\text { EB virus }}$ & $\begin{array}{l}\text { SLE } \\
\text { Control }\end{array}$ & $\begin{array}{l}37 \\
40\end{array}$ & $\geqq 1: 320$ & $\begin{array}{r}48 \cdot 6 \\
7 \cdot 5\end{array}$ & $<0.005$ & $\begin{array}{r}211 \cdot 9 \\
68 \cdot 5\end{array}$ & $<0.025$ \\
\hline Rubella & $\begin{array}{l}\text { SLE } \\
\text { Control }\end{array}$ & $\begin{array}{l}30 \\
37\end{array}$ & $\geqq 1: 256$ & $\begin{array}{c}16 \cdot 7 \\
0\end{array}$ & $<0.05$ & $\begin{array}{l}58 \cdot 4 \\
35 \cdot 1\end{array}$ & $<0.025$ \\
\hline
\end{tabular}

* Based on those with antibody. 

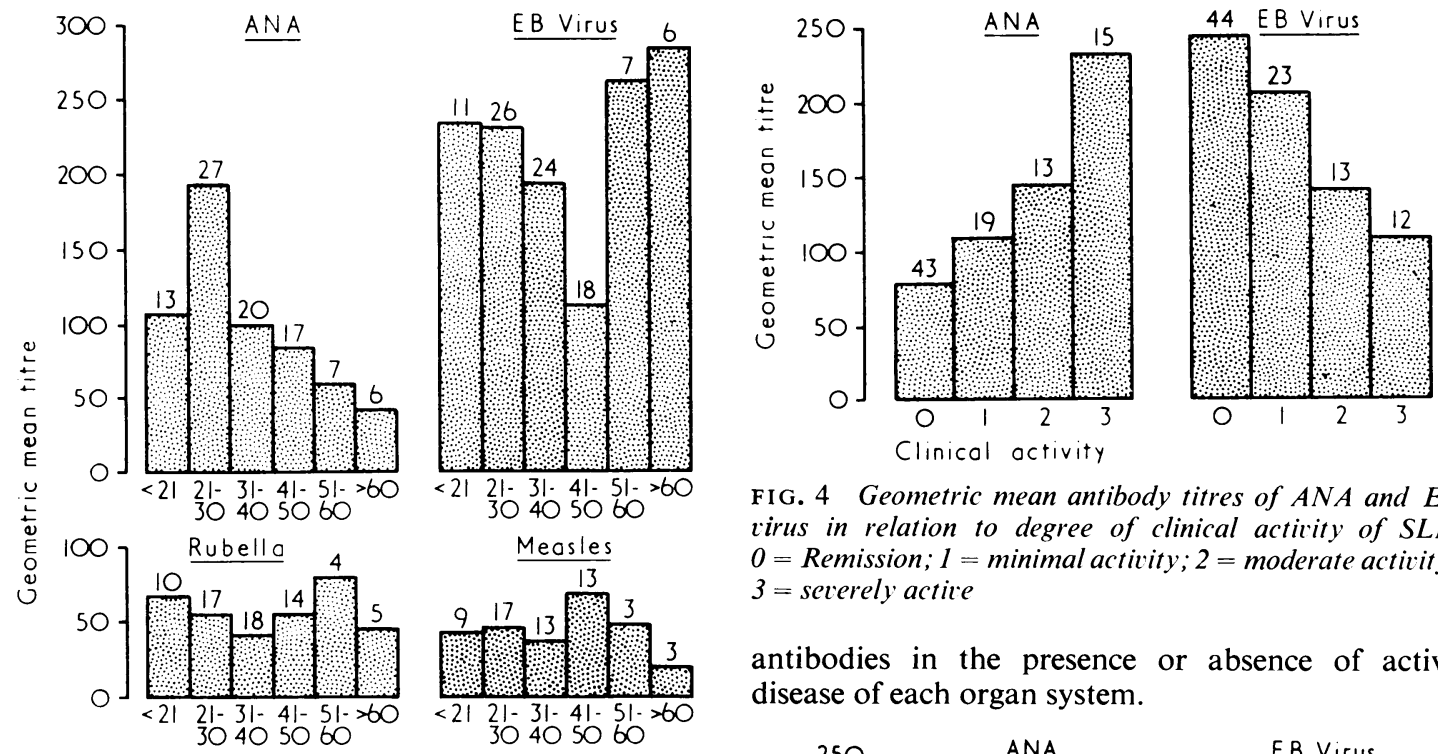

FIG. 4 Geometric mean antibody titres of $A N A$ and $E B$ tirus in relation to degree of clinical activity of SLE. $0=$ Remission $; 1=$ minimal activity $; 2=$ moderate activity; $3=$ severely active

antibodies in the presence or absence of active disease of each organ system.

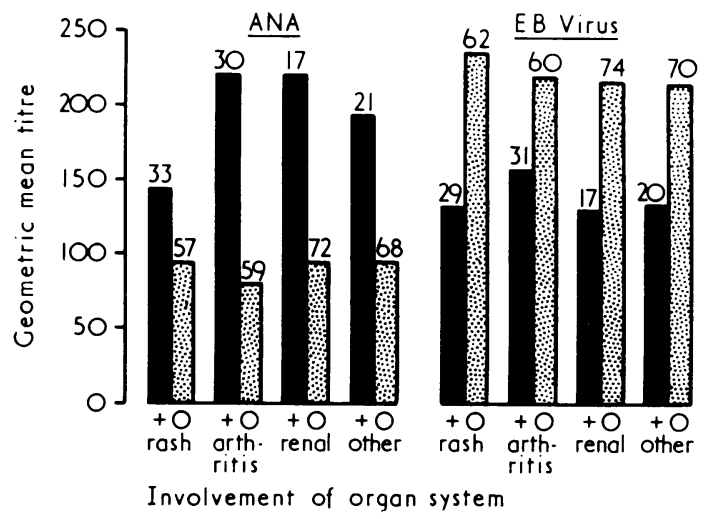

FIG. 5 Relation of geometric mean antibody titres of $A N A$ and $E B$ virus to presence or absence of organ involvement

FIG. 3 Geometric mean antibody titres in relation to age in SLE. The figures on the top of the bars are the number of cases tested. The relation to race and sex is shown in Table $V$

Table V Geometric mean titre of five antibodies related to sex and race of patients

\begin{tabular}{|c|c|c|c|c|}
\hline \multirow[t]{2}{*}{ Antibody } & \multicolumn{2}{|l|}{ Sex } & \multicolumn{2}{|l|}{ Race } \\
\hline & Male & Female & Black & White \\
\hline ANA & $71 \cdot 2$ & 116.9 & $113 \cdot 1$ & $105 \cdot 6$ \\
\hline EB virus & $176 . \overline{7}$ & $201 \cdot 6$ & $193 \cdot 7$ & $205 \cdot 1$ \\
\hline Rubella & $72 \cdot 6$ & $48 \cdot 4$ & $44 \cdot 6$ & $65 \cdot 2$ \\
\hline Measles & $80 \cdot 0$ & $42 \cdot 3$ & $59 \cdot 7$ & $50 \cdot 0$ \\
\hline Parainfluenza 1 & $40 \cdot 0$ & $22 \cdot 0$ & $31 \cdot 7$ & $20 \cdot 0$ \\
\hline
\end{tabular}

such inverse correlation of geometric mean titres with the degree of clinical activity could be demonstrated with rubella, measles, or parainfluenza 1 antibodies.

\section{ORGAN SYSTEMS}

The specific organ systems involvement at the time of study was noted. Patients were grouped as to presence or absence of activity of each specific organ system and the antibody titres compared (Fig. 5). The mean ANA titres were raised in the patients with activity. The opposite was observed for mean EB virus antibody titres which for each organ system was lowered in the group with active organ involvement. No consistent trend was observed for the other

SERUM C 3 LEVEL

This has been shown by Schur and Sandson (1968) to vary inversely with clinical activity in SLE. As shown in Fig. 6, ANA titres were highest in the presence of low $\mathrm{C} 3$ levels, whereas the mean titre of $\mathrm{EB}$ virus antibody was lowest when $\mathrm{C} 3$ level was lowest. The other virus antibodies tested did not show this correlation.

I gG LEVELS

The mean IgG level was calculated for all patients at each level of ANA, EB virus, measles, rubella, and parainfluenza 1 antibodies to determine whether high antibody titres correlated with high IgG levels. As listed in Table VI, no correlation between elevation of antibody and IgG levels was observed.

Two other analyses were made. The relation to raised antibody levels was calculated in patients with IgG levels over $1,800 \mathrm{mg}$. per cent. and those below. As shown in Table VII, no statistically significant 


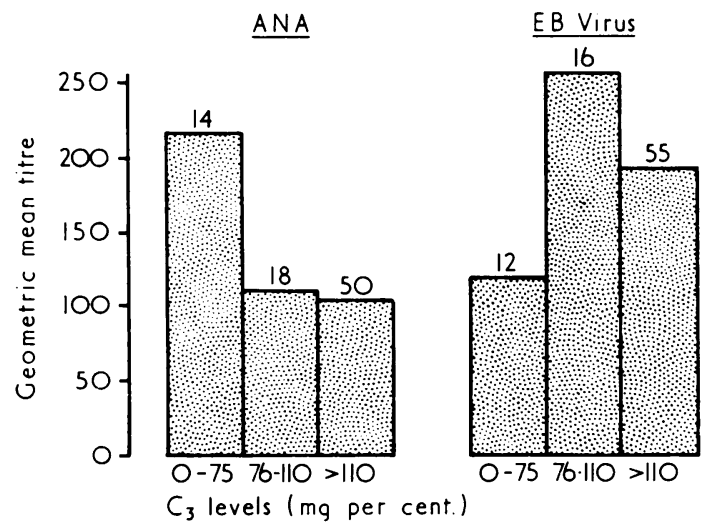

FIG. 6 Relation of geometric mean antibody titres of ANA and $E B$ virus to complement (C3) levels (mg./per cent.) correlation was found. The coefficient of correlation $(r)$ between IgG levels and each of the antibody levels was determined: none was statistically significant. Similarly, EB virus and measles antibody titres were not significantly correlated.

EFFECT OF RHEUMATOID FACTOR

Since the presence of rheumatoid factor may influence the results of complement-fixation tests (Schmid, Roitt, and Rocha, 1970; Smiley and Casey, 1969), sera tested for CF antibodies to herpes simplex, cytomegalovirus, and adenovirus were studied for the presence of rheumatoid factor. Rheumatoid factor was present in thirteen of 65 SLE sera. There was no difference in virus complement fixing antibody titres to herpes simplex, cytomegalovirus, or adenovirus between sera with and without rheumatoid factor.

Table VI Mean IgG levels* in SLE sera according to ANA and virus antibody titres

\begin{tabular}{|c|c|c|c|c|c|c|c|c|c|c|}
\hline \multirow{2}{*}{$\begin{array}{l}\text { Antibody } \\
\text { titre }\end{array}$} & \multicolumn{2}{|c|}{$A N A^{* *}$} & \multicolumn{2}{|c|}{ EB virus } & \multicolumn{2}{|c|}{ Rubella** } & \multicolumn{2}{|c|}{ Measles } & \multicolumn{2}{|c|}{ Para I } \\
\hline & No. & $\operatorname{Ig} G$ & No. & $\operatorname{Ig} G$ & No. & $I g G$ & No. & $\operatorname{IgG}$ & No. & $I g G$ \\
\hline$<1: 10$ & 5 & 2,210 & 7 & 1,814 & 3 & 1,750 & 6 & 1,979 & 3 & 2,533 \\
\hline $1: 10$ & 12 & 2,456 & 0 & - & 9 & 1,347 & 7 & 1,804 & 6 & 1,521 \\
\hline $1: 20$ & 1 & 600 & 4 & 1,288 & 4 & 3,400 & 11 & 2,068 & 5 & 2,210 \\
\hline $1: 40$ & 6 & 2,683 & 4 & 3,169 & 11 & 2,900 & 5 & 2,830 & 5 & 2,770 \\
\hline $1: 80$ & 11 & 1,911 & 11 & 2,302 & 19 & 1,959 & 18 & 2,021 & 2 & 2,225 \\
\hline $1: 160$ & 9 & 2,094 & 18 & 2,325 & 5 & 2,325 & 7 & 2,821 & 1 & 1,500 \\
\hline $1: 320$ & 15 & 1,948 & 12 & 1,913 & 5 & 1,980 & 2 & 3,100 & 0 & \\
\hline $1: 640$ & 9 & 2,536 & 12 & 2,438 & 3 & 2,500 & 0 & 0 & 0 & \\
\hline $1: 1280$ & 4 & 3,640 & 7 & 2,636 & 1 & 2,500 & 0 & 0 & 0 & \\
\hline$>1: 1280$ & 4 & 2,275 & 3 & 2,750 & 0 & & 0 & 0 & 0 & \\
\hline Total & 76 & & 78 & & 60 & & 56 & & 22 & \\
\hline
\end{tabular}

White pts.: Mean $\mathrm{IgG}=2132.5$

Black lupus: Mean IgG $=2916 \cdot 2$

Also analysed separately for blacks and whites

* Mean IgG values in mg./per 100 of duplicate tests on each serum.

* For ANA and rubella titrations, the dilution scheme used began at 1:8 instead of 1:10.

Table VII IgG levels in lupus patients as correlated with raised EB virus and measles antibody titres

\begin{tabular}{|c|c|c|c|c|c|c|}
\hline \multirow{2}{*}{$\begin{array}{l}\text { IgG level } \\
\text { (mg. per cent.) }\end{array}$} & \multirow[t]{2}{*}{ Antibody } & \multirow{2}{*}{$\begin{array}{l}\text { No. } \\
\text { tested }\end{array}$} & \multicolumn{3}{|c|}{ Per cent. of titres over level shown } & \multirow[t]{2}{*}{$\chi^{2}$} \\
\hline & & & Level & No. & $\begin{array}{l}\text { Percentage } \\
\text { elevated }\end{array}$ & \\
\hline $\begin{array}{l}\leqq 1800 \\
>1800\end{array}$ & EB virus & $\begin{array}{l}29 \\
46\end{array}$ & $\geqq 1: 160$ & $\begin{array}{l}17 \\
32\end{array}$ & $\begin{array}{l}58 \cdot 6 \\
69 \cdot 6\end{array}$ & $\begin{array}{l}\text { NS } \\
0.5\end{array}$ \\
\hline $\begin{array}{r}\leqq 1800 \\
>1800\end{array}$ & Measles & $\begin{array}{l}24 \\
32\end{array}$ & $\geqq 1: 160$ & $\begin{array}{l}2 \\
7\end{array}$ & $\begin{array}{r}8 \cdot 3 \\
21 \cdot 9\end{array}$ & $\begin{array}{l}\overline{N S} \\
0.9\end{array}$ \\
\hline $\begin{array}{l}\leqq 1800 \\
>1800\end{array}$ & Rubella & $\begin{array}{l}25 \\
35\end{array}$ & $\geqq 1: 128$ & $\begin{array}{r}3 \\
11\end{array}$ & $\begin{array}{l}12 \cdot 0 \\
31 \cdot 4\end{array}$ & $\begin{array}{l}\text { NS } \\
0 \cdot 2\end{array}$ \\
\hline $\begin{array}{r}\leqq 1800 \\
>1800\end{array}$ & Para 1 & $\begin{array}{r}7 \\
15\end{array}$ & $\geqq 1: 160$ & $\begin{array}{l}1 \\
0\end{array}$ & $\begin{array}{r}14 \cdot 3 \\
0.0\end{array}$ & $\begin{array}{c}\overline{N S} \\
0 \cdot 15\end{array}$ \\
\hline
\end{tabular}




\section{MULTIPLE ANTIBODY ANALYSIS}

The occurrence of raised antibody titres to several viruses in the same serum was analysed. Multiple elevations occurred infrequently in the same serum. Of 28 sera tested against EB virus, rubella, measles, and parainfluenza 1 viruses, none had raised titres to all, two sera had raised antibody titres to three viruses, and six had raised titres to two viruses. Of 67 sera tested against EB virus, rubella, and measles, three sera had elevated antibody titres to all three, thirteen sera had elevated titres to two viruses, and 29 sera had raised titres to only one virus.

Analyses of the mean antibody titre for groups of viruses were made in the matched SLE and tuberculosis control patients. The geometric mean antibody score for the combined group of EB virus, rubella, measles, and parainfluenza 1 antibodies was $1: 55.3$ as compared to $1: 19.8$ in the $\mathrm{Tb}$ controls; this was statistically significant by the ' $t$ ' test for matched pairs $(\mathrm{P}<0.001)$.

ANTI-DNA

Determinations were made by the modified Farr technique on 83 SLE sera. Correlation coefficients were then calculated comparing these values with the antibody titres to all eleven viruses. In not a single instance was a significant correlation obtained.

\section{SERIAL STUDIES}

Serial samples from five patients were tested to see if any ANA/EB virus correlation existed. In one patient a drop of ANA titre occurred from 1:512 to $<1: 10$ during 4 months of prednisone therapy when the anti-EB virus level remained at 1:160 or higher. Another patient was studied at the time of diagnosis and followed for 9 months after therapy had been instituted. ANA titres ranged from $1: 64$ to $1: 8$, while EB virus antibody titres remained within one titre variation. Three other patients were also studied by serial determinations of ANA. In one of these, 23 serum samples obtained over a 4-year period showed ANA titres from $1: 512$ to $1: 64$, while EB virus titres were $1: 320$ in seventeen of the sera and ranged from $1: 160$ to $1: 1280$ in the rest. Another patient who was acutely ill with CNS lupus at the time of diagnosis had an ANA titre of 1:1024 and EB virus antibody level of $<1: 10$. Eight samples obtained during massive steroid therapy during the next 2 months revealed ANA titres gradually falling to $1: 32$ with all EB virus antibody levels remaining $<1: 10$. Sera from one other patient studied over a 6-year period (12 samples) revealed ANA titres ranging from $1: 16$ to $>1: 8192$, whereas nine of twelve samples had an EB virus titre of $1: 160$, including the sample giving an ANA titre at $>1: 8192$, and the others were within a 2-fold difference of this.

\section{Discussion}

The presence of antibody to eleven virus antibodies occurred with equal frequency in sera from SLE patients as in controls, indicating no higher susceptibility to infection. However, raised antibody levels in sera possessing antibody occurred significantly more often for EB, rubella, measles, and parainfluenza 1 viruses in sera from SLE patients than in sera from healthy adults or from matched tuberculosis patients before therapy. The geometric mean antibody titre was also significantly higher for these antibodies in SLE sera. In contrast, no such elevations in titres could be demonstrated for influenza A2/Taiwan, B/gl, parainfluenza 2 and 3, herpes simplex, or cytomegalovirus antibodies. Four other laboratories have reported on virus antibody titres in SLE. Phillips and Christian (1970) showed that elevations of measles and parainfluenza 1 viral antibody titres are greater in SLE than control groups, but did not test other antigens. Hollinger and others (1971) demonstrated significantly raised titres for measles, rubella, reovirus type 2 , and parainfluenza type 2 and 3 antibodies above controls, and to a less extent for mumps and parainfluenza 1 viruses. They also presented evidence for the specificity of the response. Significantly raised titres were not found for several other viruses and for five non-human virus antigens. Hurd and others (1972) recently reported studies on twelve virus antigens in SLE patients in which, using the complement-fixation method, only measles antibodies were significantly elevated in SLE as compared with the control group. Similar results were reported by Kalliomäki and Halonen (1972), who studied the antibody titres to five viruses in SLE patients and found that geometric mean titres to measles virus were higher in SLE than in the control groups. In our much larger series of SLE patients, these studies have been confirmed for measles, rubella, and parainfluenza 1 antibodies.

Dalldorf and others (1969) have reported positive precipitin tests for EB virus using the Jijoye antigen in 34 per cent. of sera from 29 patients with SLE as compared to 5 per cent. in 582 healthy persons; some of these studies were also confirmed by the immunofluorescent technique by Carvahlo, Frost, Dalldorf, Jamra, and Evans (1971). There appears to be agreement in several laboratories that antibodies to EB virus, rubella, measles, and certain parainfluenza viruses are raised in SLE.

The EB3 cells used as the source of EB virus antigen in the indirect immunofluorescence test also fluoresce in the presence of ANA. However, the ANA and EB virus antibodies were shown to be unrelated because:

(1) Fluorescence due to ANA disappears rapidly with serum dilution and caused no confusion in 
reading slides at the levels of $1: 320$ or higher which was taken as a raised EB virus titre;

(2) Some SLE sera possessed high EB virus titres without demonstrable ANA and some sera lacked EB virus antibody in the presence of high ANA titres;

(3) No correlation between EB virus and ANA titres could be demonstrated;

(4) Absorption of six SLE sera with thymus nucleoprotein greatly reduced ANA titres or completely removed ANA without affecting the titre of antibody to $\mathrm{EB}$ virus.

Disease activity was measured by clinical manifestations, presence of specific organ involvement, and the level of $\mathrm{C} 3$. In each instance the geometric mean titre for ANA was higher in the presence of increased disease activity. In contrast, the mean titres for EB virus antibody showed the exact opposite and were lowest at times of greatest clinical activity for the entire series of patients. No such relationship between mean antibody titres for rubella, measles, and parainfluenza 1 viruses and disease activity could be demonstrated. This overall lower titre of EB virus at times of disease activity, however, was not demonstrated when serial studies of individual patients were performed. In these studies, no significant fluctuation in EB virus titres were noted during intervals of varied clinical disease activity.

In the present study, the elevated titres to EB virus, rubella, measles, and parainfluenza 1 could not be correlated with the level of IgG. Similar lack of correlation between gamma globulin levels as measured by serum electrophoresis and virus antibody titres was reported in the studies of Hurd and others (1972). On the other hand, Phillips and Christian (1971) have suggested that a correlation exists between hypergammaglobulinaemia and the level of measles and parainfluenza 1 antibodies.

The reason for elevated virus antibodies in SLE is not clear, but there is speculation that a defect in cell-mediated immunity is involved (Evans, 1971; Ziff, 1971). Such a defect might be due to genetic and/or virus induced changes. A genetic influence has been shown to exist in human SLE. This observation has been based on the demonstration of increased incidence of autoantibodies in relatives of SLE patients. This concept has been strengthened by a recent study indicating that SLE individuals show a significant association with particular human leucocyte antigen (HL-A) types (Grumet, Coukell, Bodmer, Bodmer, and McDevitt, 1971). It has previously been demonstrated that, in mice, susceptibility to a number of virus diseases is linked to the $\mathrm{H}-2$ genetic locus (Lilly, 1966). Gross leukaemia virus has been found to be associated with the renal lesion of the NZB mice (Mellors and others, 1971). Although Gross leukaemia virus is present in most strains of mice, the NZB strain is the only one which develops immune complex disease involving this agent. Thus, it may be that similar genetic influences are operative in SLE patients in whom circulating immune complexes possibly involving virus antigens or antibodies may be present.

\section{Summary}

Antibody titres to Epstein-Barr (EB) virus, measles, rubella, and parainfluenza 1 viruses were found to be significantly higher in SLE patients than in controls or healthy adults. Higher titres were not found for seven other virus antibodies. Absorption of SLE sera with nucleoprotein did not affect anti-EB virus titres. No correlation between IgG levels and virus antibody titres could be demonstrated. Serial studies on several patients revealed no significant fluctuation of EB virus titres during periods of varied clinical SLE activity. In general, the highest mean EB virus antibody levels occurred in patients with clinically inactive SLE, although no such inverse correlation could be demonstrated for measles, rubella, or parainfluenza 1 antibodies.

This work was supported by research grants from the National Institutes of Health (AI-08731) and the Center for Disease Control (CC 00242), the Connecticut Chapter of the Arthritis Foundation, the Lupus Foundation, Inc., and the Veterans Administration (627/01/7592). We thank Mrs. Betty Olson, Miss Diane DeAngelis, and Mrs. Ann Bettencourt for technical assistance, Miss Virginia Richards for statistical analysis, and Miss Marilyn Leach for secretarial assistance.

\section{References}

Carvalho, R. P. S., Frost, P., Dalldorf, G., Jamra, M., and Evans, A. S. (1971) Rev. Bras. Pesquisas med: biol., 4, 75 (Pesquisa de anticorpos precipitantes para antígeno do linfoma de Burkitt (celulas Jijoye) em soros colhidos no Brasil: English summary)

Cohen, A. S., Reynolds, W. E., Franklin, E. C., Kulka, J. P., Ropes, M. W., Shulman, L. E., and Wallace, S. L. (1971) Bull. rheum. Dis., 21, 643 (Preliminary criteria for the classification of systemic lupus erythematosus)

Dalldorf, G., Carvalho, R. P. S., Jamra, M., Frost, P., Erlich, D., and Marigo, C. (1969) J. Amer. med. Ass., 208, 1365 (The lymphomas of Brazilian children)

Evans, A. S. (1971) J. infect. Dis., 124, 330 (The spectrum of infection with Epstein-Barr virus: A hypothesis)

- Rothfield, N. F., AND Niederman, J. C. (1971) Lancet, 1, 167 (Raised antibody titres to EB virus in systemic lupus erythematosus) 
Feltkamp, T. E. W., Loghem, J. J. van, Lucas, C. J., van der NoordaA, J., De Rooy, D. J. R. A. M., AND TEN VEEN, J. H. (1971) Ibid., 1, 1182 (Antibodies to D.N.A. and viruses)

Fresco, R. (1968) Fed. Proc., 27, 246 (Tubular (myxovirus-like) structures in glomerular deposits from a case of lupus nephritis)

Grausz, H., Earley, L. E., Stephens, B. G., Lee, J. C., And Hopper, J. (1970), New Engl. J. Med., 283, 1233 (Correspondence)

Grumet, F. C., Coukell, A., Bodmer, J. G., Bodmer, W. F., AND McDevitt, H. O. (1971) Ibid., 285, 193 (Histocompatibility (HL-A) antigens associated with systemic lupus erythematosus. A possible genetic predisposition to disease)

Henle, G., AND Henle, W. (1966) J. Bact., 91, 1248 (Immunofluorescence in cells derived from Burkitt's lymphoma)

Hollinger, F. B., Sharp, J. T., Lidsky, M. D., AND Rawls, W. E. (1971) Arthr. and Rheum., 14, 1 (Antibodies to viral antigens in systemic lupus erythematosus)

Howie, J. B., AND Helyer, B. J. (1968) Advanc. Immunol., 9, 215 (The immunology and pathology of NZB mice)

Hurd, E. R., Dowdle, W., CaSey, H., AND ZIFf, M. (1972) Ibid., 15, 267 (Virus antibody levels in systemic lupus erythematosus)

Kalliomäki, J. L., ANd Halonen, P. (1972) Ann. rheum. Dis., 31, 192 (Antibody levels to parainfluenza, herpes simplex, varicella-zoster, cytomegalo virus, and measles virus in patients with connective tissue diseases)

Levy, J. A., AND PINCUS, T. (1970) Science, 170, 326 (Demonstration of biological activity of a murine leukemia virus of New Zealand black mice)

Liebhaber, H. (1970) J. Immunol., 104, 826 (Measurement of rubella antibody by hemagglutination inhibition. II. Characteristics of an improved HAI test employing a new method for the removal of non-immunoglobulin HA inhibitors from serum)

LILly, F. (1966) Nat. cancer Inst. Monsgr., 22, 631 (The histocompatibility-2 locus and susceptibility to tumor induction)

Luciano, A. A., AND Rothfield, N. (1972) Arthr. and Rheum., 15, 118 (The relationship between patterns of nuclear fluorescence and DNA-binding activity) (Abs)

Mellors, R. C., Shirai, T., Aoki, T., Huebner, R. J., and KraWczynski, K. (1971) J. exp. Med., 133, 113 (Wildtype Gross leukemia virus and the pathogenesis of the glomerulonephritis of New Zealand mice)

Norton, W. L. (1969) J. Lab. clin. Med., 74, 369 (Endothelial inclusions in active lesions of systemic lupus erythematosus)

Phillips, P. E., AND Christian, C. L. (1970) Science, 168, 982 (Myxovirus antibody increases in human connective tissue disease)

(1971) Arthr. and Rheum., 14, 180 (Virus antibody studies in connective tissue diseases)

Rothfield, N. F., Phythyon, J. M., McEwen, C., And Miescher, P. (1961) Ibid., 4, 223 (The role of antinuclear reactions in the diagnosis of systemic lupus erythematosus: a study of 53 cases)

- AND STOllar, B. D. (1967) J. clin. Invest., 46, 1785 (The relation of immunoglobulin class, pattern of antinuclear antibody and complement-fixing antibodies to DNA in sera from patients with systemic lupus erythematosus)

Schmid, F. R., RoITt, I. M., AND Rocha, M. F. (1970) J. exp. Med., 132, 673 (Complement fixation by a two-component antibody system: immunoglobulin $\mathbf{G}$ and immunoglobulin $\mathbf{M}$ anti-globulin (rheumatoid factor))

Schur, P. H., ANd Sandson, J. (1968) New Engl. J. Med., 278, 533 (Immunologic factors and clinical activity in systemic lupus erythematosus)

Singer, J. M., AND Plotz, C. M. (1956) Amer. J. Med., 21, 888 (Latex fixation test. I. Application to the serologic diagnosis of rheumatoid arthritis)

Smiley, J. D., AND CASEY, H. L. (1969) Arthr. and Rheum., 12, 698 (Decreased CF antibodies in sera and decreased lymphocyte transformation to herpes simplex in patients with rheumatoid arthritis (RA))

Wold, R. T., Young, F. E., TAN, E. M., AND FARR, R. S. (1968) Science, 161, 806 (Deoxyribonucleic acid antibody: A method to detect its primary interaction with deoxyribonucleic acid)

ZIFF, M. (1971) Ann. intern. Med., 75, 951 (Viruses and the connective tissue diseases) 